\title{
Pink plaque on the hypogastrium
}

\section{Samia Mrabat, Zakia Douhi, Sara Elloudi, Hanane Baybay, Fatima Zahra Mernissi}

\author{
Department of Dermatology, University Hospital Hassan II, Fes, Morocco
}

Corresponding author: Samia Mrabat, MD, E-mail: samiamrabat91@gmail.com

Bowen's disease is a type of intraepidermal squamous cell carcinoma usually affecting the elderly and occurring on sun-exposed areas, such as the face, scalp, and limbs. The development of Bowen's disease in other locations such as the abdomen is rare. In these cases, dermoscopy proves to be a helpful tool in making the diagnosis [1].

A 65-year-old male with no previous medical history presented himself with a nonhealing asymptomatic lesion on the abdomen slowly growing for the last ten years. A dermatological examination revealed a 6-cm well-limited erythematous plaque on the hypogastrium with peripheral pigmentation (Fig. 1). Dermoscopy found central keratin as well as white shiny structures, including white shiny lines, white shiny areas, and rosettes (Fig. 2) as well as brown linear

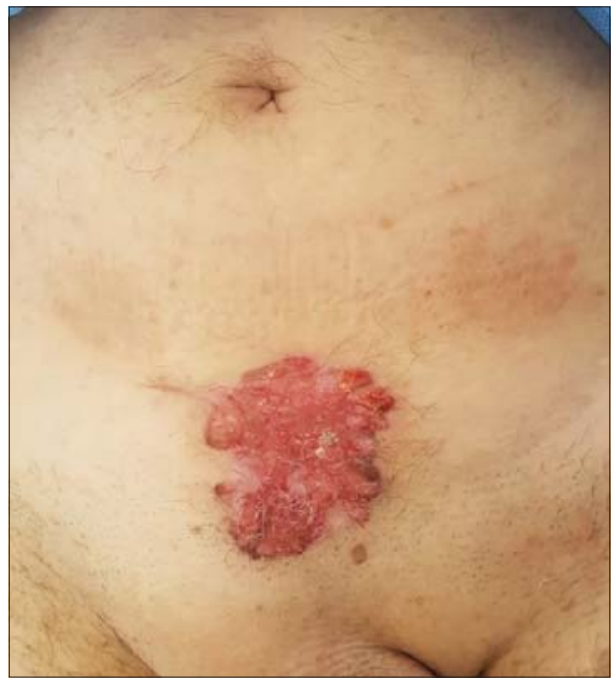

Figure 1: A well-limited erythematous plaque on the hypogastrium with peripheral pigmentation. globules and dots on the periphery and looped vessels (Fig. 3). Bowen's disease was the most likely diagnosis, which was confirmed by histopathology. The patient underwent surgery for excision of the lesion with $5-\mathrm{mm}$ margins.

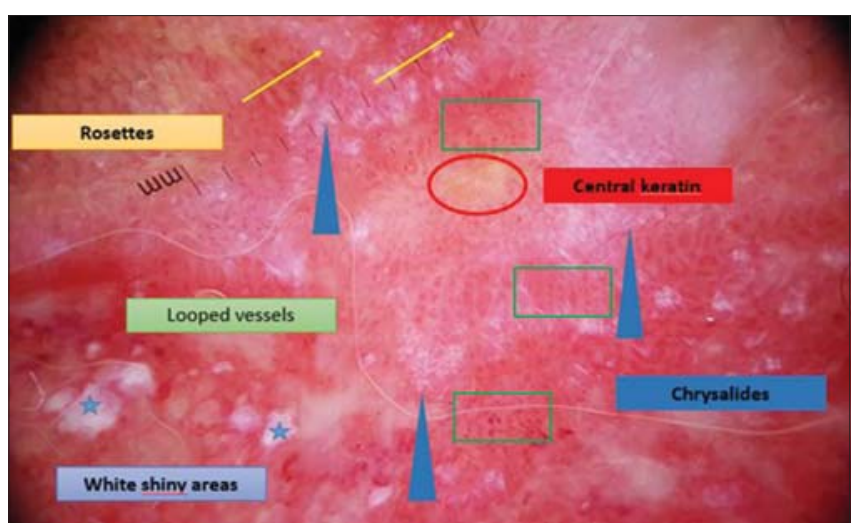

Figure 2: Dermoscopic image showing central keratin and white shiny structures (white shiny lines, white shiny areas, and rosettes).

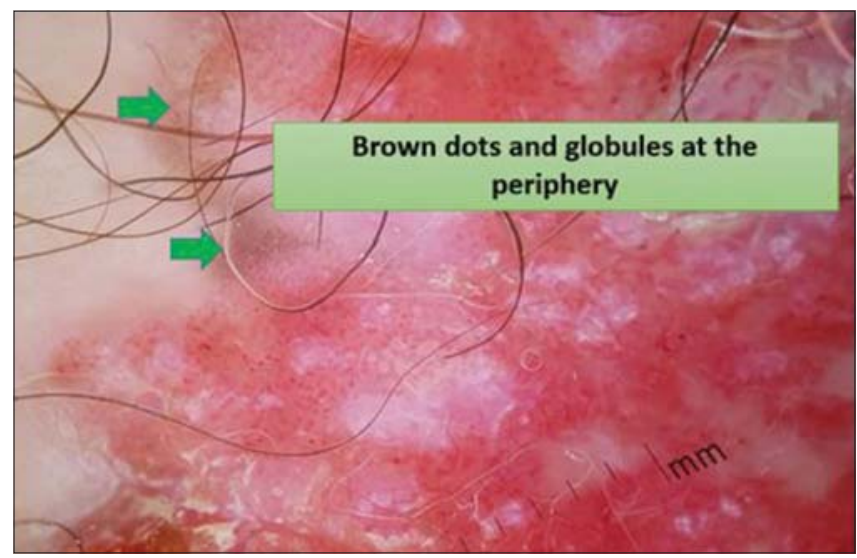

Figure 3: Dermoscopic image showing brown linear globules and dots on the periphery.

\footnotetext{
How to cite this article: Samia Mrabat, Zakia Douhi, Sara Elloudi, Hanane Baybay, Fatima Zahra Mernissi. Pink plaque on the hypogastrium. Our Dermatol Online. 2021;12(4):458-459.

Submission: 02.08.2020; Acceptance: 10.10 .2020

DOI: 10.7241 /ourd.20214.26
} 
www.odermatol.com

\section{Consent}

The examination of the patient was conducted according to the principles of the Declaration of Helsinki.

The authors certify that they have obtained all appropriate patient consent forms, in which the patients gave their consent for images and other clinical information to be included in the journal. The patients understand that their names and initials will not be published and due effort will be made to conceal their identity, but that anonymity cannot be guaranteed.

\section{REFERENCES}

1. Yu SR, Zhang JZ, Pu XM, Kang XJ. Bowen's disease on the palm: A case report. World J Clin Cases. 2019;7:2910-5.

Copyright by Samia Mrabat, et al. This is an open-access article distributed under the terms of the Creative Commons Attribution License, which permits unrestricted use, distribution, and reprodu ction in any

medium, provided the original author and source are credited.

Source of Support: Nil, Conflict of Interest: None declared. 